\title{
Del Cosmos al Caosmos en la reapropiación actual del Barroco. Una nueva normatividad para afrontar la crisis epocal
}

\author{
Luis Sáez Rueda ${ }^{1}$
}

Recibido: 24 de mayo de 2017 / Aceptado: 02 de octubre de 2017

Resumen. El ensayo pretende iluminar la crisis actual, tal y como ha sido diagnosticada por insignes corrientes del pensamiento europeo contemporáneo, desde la óptica del Barroco, especialmente el hispano. El autor defiende que una de las figuras fundamentales de lo barroco es la que llama diferencia aporética infinita. Según ello, el Barroco comprende al mundo como un conjunto de diferencias que se enlazan aporéticamente tendiendo al infinito. Esta figura se muestra, al mismo tiempo, como un operador crítico respecto a la realidad, una realidad que ha perdido su configuración pre-moderna como Cosmos. Sostiene también el autor que en su proyección actual la figura de la diferencia aporética infinita adopta la forma de una nueva normatividad, la del Caosmos, especialmente visible en el postestructuralismo y en el neobarroco iberoamericano. Ello permite distinguir dos modos de afrontamiento de la crisis actual. El caosmótico sería propio de una comprometida trans-modernidad fuerte, que contrasta con la evasiva postmodernidad débil. Tal problemática es investigada, finalmente, desde el punto de vista de la sutil heroicidad barroca y de su sombra en el presente.

Palabras clave: barroco; caosmos; desengaño; diferencia; neobarroco; postestructuralismo.

\section{[en] From Cosmos to Chaosmos in the contemporary reappropriation of the Baroque. Towards a new normativity to confront the epochal crisis}

\begin{abstract}
The essay aims to illuminate the current crisis, as it has been diagnosed by important currents of contemporary European thought, from the baroque remarkably the Hispanic perspective. The author argues that one of the fundamental figures of the Baroque is what he calls an infinite aporethic difference. According to this, Baroque understands the world as a set of differences that bind aporethically tending to infinity. This figure is, at the same time, shown as a critical operator with regard to reality, which has lost its pre-modern configuration as Cosmos. The author also holds that in its present projection, the figure of the infinite aporethic difference takes the form of a new normativity, namely, that of the Chaosmos, which is particularly visible in post-structuralism and in the Ibero-American Neo-baroque. By its virtue, it is possible to distinguish two ways of coping with the current crisis. The chaosmotic one would be characteristic of a compromised strong trans-modernity, which contrasts with the evasive weak postmodernity. This problem is finally investigated from the point of view of the subtle baroque heroism and its shadow in the present.
\end{abstract}

Keywords: baroque; chaosmos; difference; disenchantment; neo-baroque; post-structuralism.

Sumario. 1. Introducción. La clave «identidad-diferencia» en la crisis del presente ; 2. Del Cosmos al mundus, diferencia aporética infinita, en la modernidad barroca; 3. La sombra alargada del Barroco

$1 \quad$ Universidad de Granada

1saez@ugr.es

ORCID: 0000-0003-1490-3334 
y su disolución en la postmodernidad débil; 4. El Caosmos en la diferencia aporética infinita. Transmodernidad fuerte; 5. La experiencia del desengaño y el héroe barroco, transgresor en el mundo; 6. Referencias bibliográficas.

Cómo citar: Sáez Rueda, L. (2018): "Del Cosmos al Caosmos en la reapropiación actual del Barroco. Una nueva normatividad para afrontar la crisis epocal", en Revista Anales del Seminario de Historia de la Filosofía 35 (1), 51-75.

\section{Introducción. La clave «identidad-diferencia» en la crisis del presente}

Una de las razones por las que se puede afirmar un parentesco entre el modo de visión del mundo del Barroco y nuestro presente, la más inmediata, es la que afecta al problema de la crisis. Prácticamente todas las corrientes filosóficas continentales del siglo XX, y a pesar de sus distancias y oposiciones en cuanto a sus supuestos teóricos, coinciden en diagnosticar la actualidad como una crisis que se relaciona con el derrumbe de una comprensión del mundo en cuanto unitario y coherente internamente. Al respecto, y por muy simplificador que resulte, un primer acercamiento permitiría distinguir, a grandes rasgos, entre los que hacen pivotar la situación de crisis en torno a la huida de la unidad coherencial y los que, por el contrario, la remiten a la persistencia de ésta. La Escuela de Francfort y el pensamiento dialógico habermasiano-apeliano echan de menos un mundo articulado por el ideal ilustrado de una razón autónoma, vinculante en la praxis y orientadora en el progreso hacia una comunidad moral. Su ausencia habría sido sustituida por una unidad perversa, la de la racionalidad instrumental. La fenomenología existencial, el estructuralismo y el post-estructuralismo abogan, en confrontación con la línea anterior, por la afirmación de la multiplicidad inserta tanto en el mundo como en el sujeto, una multiplicidad que habría sido sometida a un allanamiento petrificador por la vocación de unidad racional. Sin embargo, la problematicidad inyectada en el término «crisis» no es hoy tan simple. Cierto que esta controversia en torno a lo uno y lo múltiple forma parte del desciframiento de su significado, pues atañe a un mundo que tiende a la globalización y que, antinómicamente, genera oposiciones beligerantes. Atañe a las dificultades propias de este presente fragmentado, que no encuentra un modo de reunión adecuado para conectar la dispersión en batalla de las voluntades, de las perspectivas valorativas, de las normatividades sociopolíticas, de los mundos de la vida, etc. Pero la comprensión de la crisis es más profunda si se realiza en términos de «identidad» versus «diferencia». Si tomamos por referencia esta otra clave encontraremos bajo las rígidas y abstractas distinciones entre movimientos filosóficos una preocupación común más sutil. Unos ejemplos bastarán para vislumbrar lo que se juega desde esta otra óptica. No es exactamente la ausencia de un Uno que ofrezca ligazón a lo disgregado del mundo lo que para los francfortianos constituía la causa fundamental de la expansión de esa racionalidad instrumental que sojuzga la dignidad humana -su autonomía-, sino más profundamente el dominio del pensamiento identitario inscrito en la praxis, que anula la singularidad diferencial de los seres humanos bajo reglas abstractas de carácter meramente estratégico y que asimila todo lo otro-extraño de lo real a la 
propiedad del sujeto ${ }^{2}$. En la línea del pensamiento dialógico, por su parte, se cifra la nueva y deseable racionalidad en las condiciones formales del discurso acerca del mundo, porque éste ya no puede ser comprendido, como expresa Habermas, desde la clave del pensamiento identitario, el cual busca en el Todo también al Uno en la unidad sustancial de lo múltiple, bien se la piense como Dios, bien como el fondo de la naturaleza ${ }^{3}$. La fenomenología existencial de Heidegger expresa la renuncia a este tipo de pensamiento, articulador de la existencia occidental, de un modo más radical, mediante la concepción de la diferencia óntico-ontológica. El logos que ha buscado nuestra historia refiere a la unidad, sí, pero originariamente como un dejar (sub)-yacer unificador que ha de tomar asiento en el ser. Y el ser no es idéntico a sí mismo, está atravesado por la diferencia entre su acontecer, en cuanto venir a presencia, y la presencia entitativa que procura ${ }^{4}$. Es precisamente el olvido de esta diferencia en el ser lo que toda la corriente heideggeriana de pensamiento sitúa en la médula de la crisis, pues reduce el ser al ente, dando lugar a una onto-teo-logía que, en general, convierte al ser en una instancia unívocamente representable y, así, domeñable, sujeta a la voluntad de dominio del hombre sobre la tierra y que, en particular, en nuestra época, la de la comprensión técnica del mundo, conduce tal representabilidad a la de las existencias (Bestände), es decir, a la de todo lo existente como cosas muertas acumulables, cuantificables y puestas a disposición del arbitrio humano ${ }^{5}$. De un modo que pretende ser más radical aún, el postestructuralismo denuncia un resto de pensamiento identitario en el tan influyente orbe heideggeriano, el cual entendería el ser todavía como intimidad en su propia esfera, como un Mismo que atravesaría inmutable y en cuanto permanente fuente iluminadora, descubridora, la diferencia de sus aconteceres, la diferencia de mundos de sentido. Será esta una cuestión fundamental para detectar la estela del barroco en nuestro presente, cuestión que abordaremos más adelante. Baste por ahora adelantar que, frente a ese resto identitario del ser en la visión heideggeriana, los más eminentes representantes del pensamiento de la diferencia -que siguen viendo en la adherencia a la identidad la clave del declive occidental- se adentran en una ontología relacional en virtud de la cual se diluye ya cualquier mismidad. En el caso del postestructuralismo francés (Foucault, Derrida, Deleuze), desplazando el ser a la inter-penetración de las diferencias, bien bajo la forma de retícula, bien bajo la de la diseminación o del rizoma. Este gesto encuentra una analogía, aunque con peculiaridades propias,

2 La dialéctica perversa inherente a la Ilustración que, persiguiendo la liberación humana respecto a poderes heterónomos, ha intensificado la opresión y la enajenación se debe, fundamentalmente -dicen Horkheimer y Adorno-, a que «La Ilustración reconoce en principio como ser y acontecer sólo aquello que puede reducirse a la unidad; su ideal es el sistema, del cual derivan todas las cosas» (Horkheimer, M./Adorno, Th. W. Dialéctica de la Ilustración. Madrid, Trotta, 2001, p. 62). Anida en esa nueva unidad una lógica identitaria que vuelve al mito haciendo que el principio de repetición reaparezca en el de legalidad, una legalidad que construye, por encima de los sujetos concretos, al Sujeto abstracto y auto-idéntico, centro de toda unidad posible y cuyo «despertar se paga con el reconocimiento del poder en cuanto principio de todas las relaciones» (Ibid., p. 64). El principio de identidad, asimismo, somete toda alteridad y extrañeza del mundo a la propiedad (Ibid., pp. 67 y ss.) y, por terminar aquí, atraviesa las relaciones de dominio en el ámbito social del trabajo y la producción, al transfigurarse en principio de convertibilidad (Cfr. Adorno, Th. W. Dialéctica Negativa. Madrid, Taurus, 1986, pp. 149-152).

3 Cfr. Habermas. J. Pensamiento postmetafísico. Madrid, Taurus, 1990, pp. 40 y ss.

4 Cfr. Heidegger, M. Identidad y diferencia. Barcelona, Anthropos, 1990, pp. 125 y ss. V., sobre esta profundización del sentido del Logos como reunión, Gadamer, H.-G. Acotaciones hermenéuticas. Madrid, Trotta, pp. 252 y ss.

5 Cfr. Heidegger, M. «La pregunta por la técnica», en Conferencias y artículos. Barcelona, Serbal, 1994, pp. 2325). 
en la llamada que hace el Neobarroco latinoamericano a un pensamiento de la mixtura o del mestizaje de los imaginarios. A través de otros cauces, tiene lugar debilitándolo, disolviéndolo en la inconmensurabilidad relativista o flexibilizándolo hasta el extremo de lo líquido. Se barrunta en este doble cauce la distancia entre una apropiación vigorosa del Barroco y una adaptación lábil y endeble, fláccida, correspondiendo esta última a los percances de una postmodernidad débil que no afronta la crisis sino que la acentúa.

En cualquier caso, esta inserción de la diferencia en la identidad produce un efecto nihilizador peculiar en la comprensión del mundo y del sujeto. La textura de ambos aparece a su luz, no sólo como la de una pluralidad de formas sin unidad, cada una de las cuales mantiene su parcial coherencia interna, su «realidad» singular. Es, de un modo más complejo, la textura de una proliferación de diferencias vinculadas por un nihil activo, es decir, por una nada de identidad que las convierte en despresencias fantasmales: en huellas, máscaras o simulacros. Esa nihilización tan específica de nuestro presente comparte con la imagen barroca del mundo su problemática quizás más genérica, la de la difusión de fronteras entre verdad y apariencia, entre la vigilia de la presencia efectiva y el sueño de su irrealidad. La impronta de lo barroco, como dice Buci-Glucksmann, se cifra en gran medida en el modo en que opera, a saber, desvaneciendo el ser, impulsando una especie de des-ser que desarrolla sus heterogéneas maneras en un teatro de operaciones ${ }^{6}$, un teatro que, como es lugar común en la bibliografía sobre el tema, se expresa en la cultura actual en un juego de lenguaje que incluye lemas como los de variación, complejidad, simulación, inconsistencia, retorización de las formas, etc.

A continuación intentaremos bucear en el mundo barroco e investigar su reapropiación actual. En el decurso, defenderemos que lo barroco está atravesado por la figura de la diferencia aporética infinita y que en la actualidad ésta se reconfigura inmanentizándola e incrustándole la figura de la diferencia caosmótica. Ello nos permitirá diferenciar una postmodernidad débil de una trans-modernidad fuerte, siendo esta última la alargada sombra en el pensamiento contemporáneo europeo y en el Neobarroco latinoamericano. Comenzaremos abordando el paso del Cosmos al mundo que se opera en la modernidad y cómo se expresa la figura de la diferencia aporética infinita en el Barroco del siglo XVII, especialmente en el hispano ( $(2)$. A continuación intentaremos explicitar la sombra de lo barroco en la Escuela de Francfort y su deformación y carácter a-normativo en variaciones de la posmodernidad débil, las cuales se caracterizan por conducir el Cosmos al Caos ( $\S$ 3). En confrontación con Heidegger, será presentado el postestructuralismo y otras corrientes estéticas y latinoamericanas como expresiones de una trans-modernidad fuerte, siendo ésta caracterizada como el movimiento que recupera la figura de la diferencia aporética infinita inmanentizándola e injertándole el carácter normativo de lo caosmótico: del Cosmos al Caosmos (§ 4). Finalmente contemplaremos la normatividad intrínseca a esta recuperación de lo barroco estudiando el modo crítico de intervención en el mundo que propicia a través de la generación de la praxis de un héroe del desengaño $(\S 5)$.

6 Cfr. Buci-Glucksmann, Chr. «la manera o el nacimiento de la estética», en Jarauta, F., Buci-Glucksmann, Chr. Barroco y Neobarroco. Madrid, Círculo de Bellas Artes, 1992, pp. 23-33. 


\section{Del Cosmos al mundus, diferencia aporética infinita, en la modernidad barroca}

La alborada de la modernidad es un tiempo de tensiones que la convierten en época de luminosa liberación y, al mismo tiempo, de desasosiego. De los escombros del comprehensivo orden medieval - dejando a un lado ahora la injusta generalización que esta calificación implica- surge una exuberante emancipación en la visión del hombre y del mundo que rompe viejas cadenas, pero también un conglomerado de nuevas ataduras que conducen a la contradicción. El amanecer renacentista asiste a una transformación ontológica de gran alcance. Puede ser emblematizada como el paso, en la interpretación de la realidad, del Cosmos al mundus. Solemos decir universo medieval, suponiendo con ello una unidad referida a la totalidad, en la que cada parte se refiere al todo. Por contraste, acostumbramos a hablar de mundo renacentista, expresión que comporta el reconocimiento de una pluralidad y de una heterogeneidad remisos a la metafísica identitaria del Todo-Uno. El Cosmos medieval se sostiene sobre los supuestos de una unidad absoluta -la confianza en una articulación total e inconcusa de lo diverso, anterior al sujeto-, de un orden clausurado -una disposición fija de las partes en el todo, orquestado por un centro absoluto-y de una totalidad cerrada -en la que el devenir y lo nuevo se sujetan a la persistencia de un Mismo inamovible. La realidad en cuanto mundo hace implosionar estos ejes a través de la vertebración heteróclita -una galaxia de mundos (culturales, ideológicos, religiosos...) en la que se ha perdido una visión universal de lo real-, del dinamismo -las circunstancias promueven profundas alteraciones económicas y sociales que obligan al cambio- y de una totalidad abierta, como si se tratase de un infinito ilimitable. Si hay un nuevo y escondido todo-uno es sólo en cuanto aplazado, diferido, al menos en esta alborada indecisa de lo moderno. El ideal de unidad coincide, paradójicamente, con «el hecho de que ya no sea posible hablar de un ideal humano unitario», a menos que se lo invoque proyectado en el futuro utópico ${ }^{7}$. En una transformación tal el sujeto que interpreta el mundo experimenta también el derrumbe de un orden que lo prefiguraba. El puesto que ocupa en el ser ya no está determinado per naturam desde las coordenadas de un macro-lugar objetivo y anterior metafísicamente a su auto-proyección. Tener una identidad implicaba, en la óptica cosmo-lógica, estar investido de un estilo ya configurado y responder a sus demandas y expectativas. Por eso, fracasar en esa responsabilidad significaba la condena, el exilio o el oprobio. En la modernidad, en la orfandad respecto a este orden antecedente, el hombre se encuentra con la inexorabilidad del hacerse a sí mismo. Y ello de modo heroico, pues en cada empresa se juega su propio ser; si fracasa, no incumple una prescripción, sino que pierde su propia auto-generación; el temor al fracaso trasciende al de defraudar una expectativa puesta en él y se cifra ahora en el pavor a la pérdida de su ser: surge, como envés de la experiencia de libertad, una nueva forma de angustia, la del horror vacui, ante la que ha de hacerse valer épicamente, extrayendo de su fondo informe coraje y resolución para darse a sí mismo una forma ${ }^{8}$.

Heller, A. El hombre del Renacimiento. Barcelona, Península, 1980, pp. 24-25. Cfr. pp. 7-32.

8 Cfr. Taylor, Ch., Fuentes del yo. Barcelona, Paidós, 1996, pp. 28-33. 
Contemplada desde esta perspectiva, la modernidad, en la que se va a incrustar el gesto barroco, lleva incoado, a pesar de que lo defraude en su devenir ulterior, ese giro que en nuestra contemporaneidad es caracterizado como el derrumbe del pensamiento de la identidad por mor de un pensamiento de la diferencia, al cual hemos aludido. Sí, se diría que tal deflagración está en germen en la modernidad. A los rostros cosmo-lógicos de la unidad absoluta, del orden clausurado y de la totalidad cerrada subyace la comprensión de una realidad idéntica a sí misma, mientras que el emblema mundo pivota sobre la diferencia: desigualdad del mundo respecto a sí mismo, condición de que genere desde sí lo múltiple-heterogéneo en dinamismo abierto. Y la diferencia atraviesa también el sentido de lo humano. Su ser diferencial, vislumbrado en esta época, se cifra, a nuestro juicio, en una inadecuación consigo mismo que lo fuerza a la resignificación perpetua del sentido de su ser. Pero la modernidad no llega a saciar este carácter diferencial del mundo y del hombre; retiene su impulso al remitirla a esa nueva identidad consigo mismo que es el sujeto cartesiano y sus sucesivas máscaras, proyector que selecciona de la diversidad real sólo aquello que es pensable desde su interna certitudo y que abre un ideal que llega hasta nuestros días: el de sistematizar la realidad en una Mathesis Universalis, ciencia del orden y la medida.

Es en el Barroco donde el ser diferencial del mundo y del hombre aparece sin una reducción a la identidad, pues introduce en la diferencia tensiones dramáticas e insolubles. Y ello a través de dos vías paralelas y recíprocamente afectantes, una relativa al devenir material, otra a una comprensión ontológica del mundo. Explicitemos la primera. La revolución renacentista empujaba a un hombre resuelto y, salvo en raras excepciones, confiado. La apelación a la autotransformación estaba envuelta todavía en el panegírico, en la exaltación de una humanidad grandiosa, pues su versatilidad y su ilimitación descubiertas «representaban conjuntamente la substancia del hombre (...), a consecuencia de lo cual se pudo afirmar que el hombre era capaz de todo» ${ }^{9}$. En el Barroco se desmorona semejante arrojo en lo que posee de candidez, pues en él surge la experiencia de que la maleabilidad del mundo heteróclito y abierto corre paralela, paradójicamente, con una oscura y potente resistencia a dejarse recrear por el hombre, por su aventura auto-transfiguradora. Desde mediados del siglo XVI y durante el XVII, toda una nueva estructura material introduce procesos que amenazan con autonomizarse y desprenderse de la voluntad humana, como si de nuevo un intra-cosmos se injertara en el mundo. Los factores que dirigen la economía y la política se vuelven cada vez más oscuros y más difíciles de gobernar desde lo concreto. Las fuerzas del capital muestran el vigor de su inercia inmanente; rebasan el papel revolucionario que habían ejercido respecto al orden feudal y, por decirlo con la fúnebre metáfora de Marx y Engels, «toda esta sociedad burguesa moderna, que ha hecho surgir tan potentes medios de producción y de cambio, se

$9 \quad$ Heller, A. op. cit., pp. 457-458. Con ironía alude Nietzsche a la necesidad de un impulso semejante, el del quererlo todo característico de esa «despiadada curiosidad» que rompía con «la prolongada falta de libertad del espíritu (...), la disciplina que el pensador se imponía dentro de una regla eclesiástica o cortesana o bajo presupuestos aristotélicos». Ironía, decimos, porque al mismo tiempo denosta su ingenuo exceso, a saber, el «laisser aller» confiado en su ilimitada libertad (Nietzsche, F. Más allá del bien y del mal. Madrid, Alianza, 1997, parte V, $\S 188$, p. 127). Propio del inicio de la modernidad es ese furor hacia la plenitud en la realización de lo humano por la curiositas, un propulsor que atraviesa todo el Renacimiento como una fuerza jovial, capaz incluso de encontrar conciliación -en el nuevo naturalismo- con los antiguos reparos bíblicos al árbol del conocimiento (Cfr. Blumenberg, H. La legitimación de la Edad Moderna. Valencia, Pre-Textos, 2008, pp. 379404). 
asemeja al mago que ya no es capaz de dominar las potencias infernales que ha desencadenado con sus conjuros» ${ }^{10}$. La situación política da lugar a una organización peculiar. A pesar de que el poder en Europa basculó del imperio español al poderío francés, la época se fundaba en el absolutismo. Queda iluminada como la gesta de grandes potencias administradas de modo centralizado que degluten en un novedoso todo-uno lo diferente. Surge, en general, la experiencia de un mundo atravesado por procesos ingobernables e indisponibles bajo el manto de una dinamicidad enorme ${ }^{11}$. El significado de la crisis barroca pivota, en gran medida, en esta contradicción que rompe la apariencia de armonía presente en el Renacimiento. Todo parece seguir el destino de esas figuras míticas que serían más tarde Fausto y Frankestein: por un lado, la apertura del mundo expande los poderes humanos, pero, al mismo tiempo, libera fuerzas demoníacas. De ahí que la experiencia del desengaño imante toda la visión barroca, como veremos más adelante. Entre hombre y mundo se erige ahora un desencuentro. Don Quijote es prueba viviente de que el ideal está condenado a ser obviado por la realidad y la ruptura con el orden anterior se pone de manifiesto en la convulsión del orden ético-moral, pues el héroe, ora ridículo, ora sublime, es santo y loco a un tiempo. El pensamiento literario, en general, denuncia que el hombre, en semejante discordancia, se vea obligado a una vida invertida. Lo escribió de forma bellísima Baltasar Gracián, el inmortal y emblemático pensador del barroco hispano:

Todo va al revés en consecuencia de aquel desorden capital: la virtud es perseguida, el vicio aplaudido; la verdad muda, la mentira trilingüe; los sabios no tienen libros y los ignorantes librerías enteras; los libros están sin doctor y el doctor sin libros; la discreción del pobre es necedad y la necedad del poderoso es celebrada. ${ }^{12}$

El segundo factor barroco de convulsión introduce la contradicción en el mundo mismo. El siglo XVII, espacio aún esencialmente religioso, está impregnado, como ha mostrado con lucidez y minucia L. Goldmann ${ }^{13}$, por la experiencia del Deus absconditus. Se trata de una experiencia agónica. Estando necesitado el mundo, en su facticidad y contingencia, de lo eterno divino como fundamento de su sentido y habiéndose retirado éste, al mismo tiempo, a empellones de la desacralización racionalista, el hombre se encuentra en una tesitura tensional, brecha o intersticio entre opuestos irreconciliables. El mundo, sin su fundamento absoluto, es experimentado como una facticidad herida en su interior por la nada, es decir, por la ausencia de plenitud que demanda desde sí. Por otro lado, esa plenitud y perfección a la que remite la comprensión del mundo, es ausente, ya no es un plenum, sino lo necesario imposible.

Si vinculamos ahora las dos contradicciones podemos contemplarlas bajo una única figura con diferentes rostros: la de lo aporético infinito (y diferencial). La controversia entre el hombre y el mundo es contemplada desde el Dios ausente. El mundo es experimentado como todo y nada al unísono. Por decirlo con Gauchet, el alejamiento del absoluto, su ser escondido, afirma por contragolpe la totalidad finita del mundo. Lo visible y lo invisible parecen ajustarse en él, se ensamblan

\footnotetext{
Marx, K. y Engels, F., Manifiesto comunista, Madrid, Akal, 1997, p. 28.

Cfr. Hauser, A. Historia social de la literatura y el arte. Barcelona, Labor, 1992, Vol. 2, caps. VI y VII.

Gracián, B. El Criticón. Madrid, Cátedra, 2004, I, cr. 6a , p. 146.

V. Goldmann, L. El hombre y lo absoluto. El dios oculto. Barcelona, Península, 1985, caps. II-IV.
} 
por todos los puntos como una sola e idéntica realidad y el hombre puede ya reconocerse como agente en la lucha con lo que lo envuelve. Pero, por ese mismo acto, y paradójicamente, el mundo se reconoce atravesado por una nada: es imposible alcanzar una totalización, pues el origen absoluto que permitía aprehenderlo como tal se ha convertido en inaccesible. El todo mundanal es ahora presente y ausente al unísono, es problemático $\mathrm{y}$, como tal, infinitamente descifrable ${ }^{14}$. Con ello es congruente que, al mismo tiempo, el criterio de esta infinita e imposible totalización sea el de un infinito ideal aporético, pues el absoluto es también un todo al que apunta la mirada y una nada, en cuanto ausente.

La cuestión crucial, pues, se juega en esta reunión aporética de presencia y ausencia infinitas, tanto en el mundo como en la trascendencia criteriológica a la que aspira. Y ello quiere decir, en la línea de nuestra argumentación, que no es simplemente el problema de lo múltiple y lo uno el que articula la imagen barroca del mundo, sino el de la identidad y la diferencia. Ni el mundo infinito en su finitud ni el infinito que lo sustentaría son realidades idénticas a sí mismas; son identidades supuestas y apeladas, pero atravesadas en su interior por la herida de su heterogeneidad o diferencia. Semejante textura puede ser reconocida en Pascal. Su Dios oculto es un «Dios presente y ausente, y no presente unas veces y ausente otras, sino siempre presente y siempre ausente $\rangle^{15}$, una falta de identidad consigo mismo que se especifica en los dos infinitos, en el mundano y en el trascendente ${ }^{16}$. En el ámbito hispano hay toda una eclosión de esta figura de pensamiento y experiencia, que tiene su más clara expresión en B. Gracián. El mundo rebosa de una infinita variedad de seres y formas en las que, como le dice Andrenio a Critilo en El Criticón, se expresa «un Criador de todo, tan manifiesto en sus criaturas y tan escondido en sí (...) tan oculto que es conocido y no visto, escondido y manifiesto, tan lexos y tan cerca». «No se ve, pero se conoce; (...) estando retirado a su inaccesible incomprehensibilidad», nos habla por medio de sus criaturas»», precisa $\mathrm{Critilo}^{17}$. El infinito no es ajeno al mundo: está en él, en el trenzado de sus diferencias, pero, paradójicamente, en la forma de un testimonio de su retirada. El juego de presencia y ausencia simultáneas no se da aquí sólo en lo infinito trascendente (que es y no es, como absoluto pulverizado en su huida), sino también en el terrenal, multívoco juego de realidades diferentes en el que aquél opera en la justa medida en que se aparta, se detrae y se hunde en su secreto. Por eso, para el Barroco europeo en general -y con especial intensidad el hispanohay dos infinitos, nos dice B. Pelegrín: el microscópico, que es el mundo cifrado, como un libro interminable y en jeroglífico, en parataxis sin cese, y el telescópico, el libro total desde el que virtualmente se mira, porque subyace a todas sus expresiones

14 Cfr. Gauchet, M. El desencantamiento del mundo. Una historia politica de la religión. Madrid/Granada, Trotta/ Universidad de Granada, 2005, caps. III y IV.

15 Goldmann, L. El hombre y lo absoluto, op. cit., p. 51.

16 «Para ir hacia la nada no hace falta menos capacidad que para ir hasta el todo; se necesita una capacidad infinita para una y otra cosa» (Pascal, G. Pensamientos. Madrid, Alianza, 1986, fr. 72). «Bogamos en un amplio medio, siempre inseguros y flotantes, empujados de un lado a otro. Si hay algún punto en el que creamos poder afirmarnos y unirnos a él, se tambalea y nos abandona, y si le seguimos, se nos escapa, se desliza y huye en una eterna huida. (...) Ardemos en el deseo de encontrar un asidero firme y una última base constante para edificar sobre ella una torre que se eleve hasta el infinito, pero nuestro fundamento se hunde y la tierra se abre hasta los abismos» (Ibid., fr. 72).

17 Gracián, B. El Criticón, op. cit., I, cr. 3ª pp. 94-95. De un modo aforístico: «Este mundo es un cero: a solas, vale nada, juntándolo con el cielo, mucho» (Gracián, B. Oráculo Manual y arte de prudencia. Madrid, Cátedra, 1997, 211). 
como la esperanza de un desciframiento que no llega a cumplirse jamás y que acaba en el rotundo silencio ${ }^{18}$.

Tal infinito diferencial aporético lo logra expresar el Barroco a través de específicas formas de representación, que leen en el mundo una teatralidad por mor de la cual su identidad sustraída da lugar a una yuxtaposición diferencial de comparecencias sin remisión a un fundamento discernible. El imaginario graciano es siempre ambiguo. Todo en el mundo es dual, él y su otro simultáneamente: las edades de la vida, según se las mire de un modo negativo o positivo; la muerte, tirana pero consoladora; la gravedad, que puede expresar la seriedad enérgica de la vida o su pesadez mortecina y hasta irrisoria; la ligereza, que puede expresar frivolidad o grano de gracia divina ${ }^{19}$. Tal ambigüedad, inherente a cada realidad, vulnera la unidad consigo del mundo, el cual se trueca en un simulacro que «conjuga lo mismo y su otro» ${ }^{20}$, traspasable sólo «por un rapto último de trascendencia, que aún pervive en los héroes del drama barroco» ${ }^{21}$. El hombre mismo es un teatro o simulacro en su propia esfera, un alterutrum, lo uno y lo otro ${ }^{22}$. Todo ello depende de un operador barroco general, el de «la escenificación teatral del infinito» ${ }^{23}$. El infinito es señalado o connotado en lo finito y el sentido de su representación mundana se hace depender también de su propia infinitización. Una infinitización, como decimos, que trabaja por diferenciaciones aporéticas, en las que cada representación, lejos de remitir a un Mismo, lanza su significación a lo otro de sí. En este punto resulta esclarecedora la distancia que Benjamin explicita entre el símbolo, modo de temporalización romántica, y la alegoría, propia de lo barroco ${ }^{24}$. El símbolo es la encarnación de la Idea, de un plenum que se ofrece en cada concreción manifestativa suya. Expresa un «presente eterno», una «momentánea totalidad» ${ }^{25}$. Y en esa encarnación simbólica la Idea permanece «igual a sí misma» ${ }^{26}$. En la alegoría, por el contrario, el drama se construye en medio de la huida de semejante plenum. De ahí que la Idea sea introducida en el flujo del tiempo, torrencial y dramáticamente móvil, pero dinamitada y extirpada de su totalidad: en tal flujo alegórico, todo ser aparece separado de la gracia redentora, como «ruina» en una acumulación incesante de fragmentos efímeros «a la espera permanente de un milagro» ${ }^{27}$. La historia, así, «se redujo sensiblemente a escenario», y no "como proceso de una vida eterna», más bien como decadencia incontenible» ${ }^{28}$. Si hay redención de la ruina es sólo en la

18 Cfr. Pelegrín, B. Figurations de l’infini. L’âge baroque européen. París, Seuil, 2000, pp. 195-389.

19 Cfr. Cerezo, P. El héroe de luto. Ensayos sobre el pensamiento de B. Gracián. Zaragoza, Institución Fernando el Católico, 2015, VI, § 5 («El Barroco, cultura de la ambigüedad»), pp. 229, 234.

20 Ibid., p. 229.

21 Ibid., p. 233.

22 «El que parece sabio, el que valiente, el entendido, el zeloso, el beato, el cauto más que casto, todos passan en cifra de alterutrum» (Gracián, B. El Criticón, op. cit., III, cr. 4ª p. 621).

23 Cfr. Trías, E. «Escenificación del infinito (interpretación del Barroco)», en Lo bello y lo siniestro. Barcelona, Ariel, 1996.

24 Cfr. Benjamin, W. El origen del 'Trauerspiel'alemán, en Obras Completas. Madrid, Abada, 2006, Libro I, Vol. I, pp. 217-459, especialmente pp. 375-436 («Alegoría y Trauerspiel»).

25 Ibid., p. 381.

26 Ibid., p. 402. «Es el signo, cerrado en sí, comprimido y persistente constantemente en sí, de las Ideas» (Ibid., p. 382).

27 Ibid., p. 397.

28 Por eso, el emblema del Barroco es la calavera (Ibid., p. 383). «En la alegoría la facies hippocratica de la historia se ofrece a los ojos del espectador» (Ibid.), presenta a la «criatura excluida de la gracia» (Ibid.). En el símbolo lo empírico y lo trascendente pleno aparecen instantáneamente fusionados, mientras que en la alegoría el tiempo se expresa en una naturaleza mortificada, «no en el brotar de la yema y en la flor, sino en lo marchito y decadente de sus criaturas» (Ibid., p. 398). 
antinomia persistente, que llega a la polisemia, porque cada cosa, como alcanzada por un halo proteico, puede significar ahora cualquier otra; esta polisemia se extiende en la inmanencia mundanal, rompe la identidad de cualquier entidad, introduciéndola en una remisión continua a lo otro de sí y elevándola en virtud de esa alusión que la hace inconmensurable y todas las cosas al mismo tiempo ${ }^{29}$. ¿No es este el mundo graciano, cuyo ser es el de un emisario de Proteo, «muchos en uno, porque ya era blanco, ya negro; ya moço, ya viejo; ya pequeño ya grande; ya persona y ya fiera ${ }^{30}$ ? La comprensión que del Barroco posee Deleuze completa la visión de esta realidad metamorfoseante que rehúye la identidad inflamándola de relaciones diferenciales. El autor francés aplaude expresamente la interpretación de Benjamin para acompañarla $\mathrm{y}$ expandirla mediante la introducción del pliegue como clave del Barroco ${ }^{31}$. A diferencia del símbolo, que «combina lo eterno y el instante casi en el centro del mundo», la alegoría barroca presenta un mundo descentrado. Como las mónadas leibnizeanas, cada singularidad mundana, en lo alegórico, contiene al universo entero en su perspectiva y, siendo como una punta, lo eleva hacia él: el mundo como cono. La multiplicidad no se relaciona en función de un centro, sino de un vértice concreto. Pero ello implica introducir la Idea absoluta en una red intramundana de relaciones diferenciales y, sin embargo, extraerla al mismo tiempo como conjunto, pues sucede que, por una parte, hay una multitud de singulares-vértice monádicos, cada uno de los cuales expresa el mundo entero en una variedad peculiar, y que el mismo mundo, por otra, no existe fuera de sus expresiones. La variedad no es unificada por recurso a una mismidad subyacente, entonces, sino plegada en armonía, unidad armónica que «permite pensar lo existente como derivando de lo infinito» ${ }^{32}$. Tal conformación de la realidad corrobora, por lo demás, que es el problema de la identidad y la diferencia aporética el que susurra en el Barroco. Es el juego, en este caso, entre la presencia de lo infinito en cada singularidad diferencial y el de su ausencia en el entramado global, un juego de claroscuro también actuante en cada concreción monádica, cuyo descentramiento en cono introduce la inadecuación en su seno: entre la claridad armoniosa que selecciona y la oscura e infinita profundidad de pliegues y repliegues en su fondo, que ya no es selección, sino el mundo en toda su amplitud. Diferencia aporética, tanto en el conjunto como en cada elemento suyo y llevada al infinito. La luminosidad de lo idéntico es desmembrada, en su propio ser, por esta aporética diferencial que representa su proliferación de luminarias. Es lo que ha llamado Buci-Glucksmann «la locura del ver», un ver desde mil lugares, en multitud de anamorfosis puestas en escena, un ver aporético, pues es simultáneamente, en su envés, un oscuro no-ver: en cada visión está sustraída la vista que cada otra posee sobre ella. Un drama luminoso de relaciones atravesadas por el poder de la sombra, que se extiende a toda nuestra pintura del XVII y que juega no sólo en Gracián, sino -en teatro de símiles, metáforas, juegos de palabras- en el conceptismo de

29 De tal modo que «una misma cosa podía simbolizar tanto una virtud como un vicio, es decir, todo en definitiva. (...) Cada personaje, cada cosa y cada situación puede significar cualquier otra. (...) [Y así,] precisamente por aludir a algo distinto, cobran una potencialidad que los hace parecer inconmensurables con las cosas profanas y las eleva a un plano superior, pudiendo incluso llegar a santificarlas. Según esto, en la consideración alegórica el mundo profano aumentará de rango en la misma medida en que se devalúa» (Ibid., p. 393).

30 Gracián, B. El Criticón, op. cit., I, cr. VII, p. 153.

31 V. Deleuze, G. El pliegue. Leibniz y el Barroco. Barcelona, Paidós, 1989, pp. 161 y ss.

32 Ibid., p. 165. 
Quevedo, en el culteranismo de Góngora, en Lope de Vega tanto como en Calderón ${ }^{33}$. Independientemente de su materialización en Leibniz - cuyo Dios es, tal vez, «el más barroco posible $\aleph^{34}$ - el pliegue, como función operatoria del Barroco en general, testifica el infinito aporético-diferencial que nosotros hemos tomado por emblema de esta época. Pues su enjundia desborda el problema de lo uno y de lo múltiple. En él no son vinculadas partes en un todo, o de otro modo, puntos en una línea flexible, auto-idénticos y sumados, como granos de arena en la costa. Es un continuo infinito cuyas partes han sido transmutadas en formas del pliegue. Según ello, lo múltiple «es lo que está plegado de muchas maneras» ${ }^{35}$. Cada mundo, cada ser, es un repliegue en el pliegue, el cual, por su carácter plástico y elástico, reúne lo diverso arrebatándole su auto-consistencia: comprime espacios, creando así mundos como «agregados» por compresión, lo que implica que en otras inflexiones del pliegue se está produciendo una des-agregación distorsionante. Cada cosa, pues, está sometida al devenir incesante del desmoronamiento de su identidad, al ser reconfigurada por la diferencia con sus otros $^{36}$. Pero, además, la diferenciación lleva aparejada una aporética del claroscuro, pues el pliegue es como una musculatura cuyo resorte actúa en todas partes ${ }^{37}$, de tal modo que cada singularidad contiene en sus repliegues infinitos la imagen negativa de las otras ${ }^{38}$.

\section{La sombra alargada del Barroco y su disolución en la postmodernidad débil}

¿Por qué podemos decir que la crisis de nuestro presente incluye al Neobarroco como clave privilegiada para comprenderla? Sobre esta cuestión se ha escrito mucho, pero siguiendo el hilo de nuestra reflexión (que no es excluyente respecto a otras interpretaciones) diremos que la problemática a la que nos enfrentamos hoy es, de nuevo, la de encontrar el modo de vincular los fragmentos y figuras heterogéneas de nuestra visión del mundo, no desde el operador de lo uno y lo múltiple, sino desde el de la identidad y la diferencia. Como hemos señalado, es esta clave la que dirige, en su profundidad, la práctica totalidad de los diagnósticos sobre nuestra crisis en el pensamiento contemporáneo. A ello hay que añadir que, como en el Barroco del XVII, nos experimentamos en contradicción con el mundo. Atravesado éste por fuerzas que parecen ingobernables (la racionalidad estratégicoinstrumental, la ontificación del ser, la autonomización de las leyes del mercado en un neoliberalismo tenaz, etc.), nos impulsa a sentirnos quijotescamente en guerra con él, al que juzgamos gracianamente como invertido, pues en su robustez respecto a nuestras acometidas liberadoras eleva lo vil y degrada lo noble, como si realmente

33 Cfr. Buci-Glucksmann, Chr. La folie du voir. Une esthétique du virtuel. París, Galilée, 2002, libro segundo, especialmente pp. 91-131.

34 Echeverría, J. «Leibniz: el Dios más barroco posible», en Jarauta, F., Buci-Glucksmann, Chr. Barroco y Neobarroco, op.cit., pp. 45-59.

35 Deleuze, G. El pliegue, op. cit., p. 11. Cfr. todo el capítulo 1.

36 Ibid., pp. 14 y ss.

37 Ibid., pp. 15 y ss.

38 Si lo referimos a Leibniz, «Todo lo que excede mi zona clara o mi departamento, y que sin embargo yo incluyo (...) es como la imagen negativa de otras mónadas, porque otras mónadas lo convierten en su zona clara. (...) Por supuesto, ninguna mónada contiene otras, pero mis posesiones intrínsecas implican suficientemente la marca de extraños cuya sombra descubro en mí, en mi sombrío fondo, puesto que no hay nada oscuro en mí que no deba ser clasificado en otra mónada» (Ibid., p. 138. Cfr. cap. 8). 
se estuviese cumpliendo el presagio nietzscheano de la expansión del desierto. Ahora bien, ya no disponemos de una trascendencia absconditus. La muerte de dios, proclamada por Nietzsche, recorre todo nuestro espectáculo próximo. La incógnita inquietante que emerge en este reduplicado retiro de lo absoluto es la de si nuestro mundo, a falta de otras soluciones, ha podido restaurar en la inmanencia al menos ese operador salutífero, contrapunto para domeñar la crisis, al que hemos llamado diferencia aporética infinita. Responderemos intentando mostrar, en primer lugar, que ésta no ha llegado a ser revigorizada de un modo intenso hasta la mitad del siglo $\mathrm{XX}$, pero que aún en ese espacio ha recibido la proyección de su alargada sombra; en segundo lugar, defendiendo que ya avanzado el pasado siglo y en la actualidad emerge reforzada y más completa, pero indecisa entre una postmodernidad débil, que la hace fracasar, y una trans-modernidad fuerte, que la reinstaura. La primera nos conduce del Cosmos al Caos; la segunda, del Cosmos al Caosmos.

Hay, en efecto, una alargada sombra del barroco en el mundo contemporáneo, un conjunto de gestos que lo actualizan. El derrumbe nietzscheano de Dios no es simplemente el de un Cosmos como unidad total. Es, más bien, el de un socavamiento de la identidad desenmascarando en ella diferencias entre fuerzas, como en el caso del Yo o del Sujeto y el de las pasiones. «El hombre como una multiplicidad de 'voluntades de poder $\rangle^{39}$. ¿No es la voluntad de poder, ella misma, una identidad surcada por esas diferencias, incluso aporéticas (fuerzas activas y reactivas en reunión discordante)? Como voluntad de crecimiento, es vida que aspira a más vida, a su intensificación, es decir, un impulso a diferenciarse respecto a ella misma de modo infinito, arrastrando con ello al hombre a la necesidad de hacerse proteico, autogenerador. Por eso se han realizado intentos de vincular a Gracián y a Nietzsche ${ }^{40}$. Tal vez sea Nietzsche el que abre la rendija para que penetre la sombra alargada del Barroco en nuestra época.

En los francfortianos late un murmullo neobarroco. Dado que el pensamiento identitario está a la base del mundo administrado, la totalidad social aparece como engaño y ficción: «El Todo es la Falsedad», sentencia un Adorno pesimista ${ }^{41}$, como rememorando ese todo-nada del mundo que vibra en el Barroco. El todo identitario ha expulsado lo $\mathrm{No}_{\text {-Idéntico }}{ }^{42}$, tal y como para Benjamin la identidad de la historia como continuum, narrada desde los vencedores, ha segregado lo diferente maldito como multiplicidad de víctimas ${ }^{43}$. Es aquí donde aparece lo diferencial aporético. Frente a ese teatro del todo social, del que se diría que es un sueño fantasmagórico trabado de fraude, trampa, mentira y artificiosa seducción - pues hace pasar con mil tretas a la razón instrumental por la autónoma ${ }^{44}$ - y aporético - pues esa contradicción pertenece

39 «El hombre como una multiplicidad de 'voluntades de poder': cada una con una multiplicidad de medios expresivos y formas. Las presuntas 'pasiones' singulares (p. ej., el hombre es cruel) son sólo unidades ficticias, en la medida en que aquello que, proveniente de los diferentes impulsos básicos, entra en la conciencia como algo homogéneo es imaginariamente unificado de modo sintético en un 'ser' o una 'facultad', en una pasión. De la misma manera pues en que el 'alma' es una expresión de todos los fenómenos de la conciencia» (Nietzsche, F. Fragmentos póstumos. Madrid, Tecnos, 2006, Vol. IV, 1 [58], pp. 52-53).

40 Por ejemplo, Rouveyre, A. y Bouillier, V. B. Gracián y F. Nietzsche. Madrid, Ediciones Biblos, 1930.

41 Adorno, Th. W. Dialéctica Negativa, op. cit. p. 14.

42 Cfr. Ibid., 11-62.

43 V. Benjamin, W. Angelus Novus. Barcelona, Edhasa, 1966.

44 Marcuse es especialmente incisivo en el análisis de tales tretas que racionalizan el sistema represivo, como la euforia en la infelicidad, la creación de necesidades falsas o la desublimación represiva. V. Marcuse, H. El hombre unidimensional. Barcelona, Ariel, 1981, especialmente capítulos 2 y 3. 
a la realidad ${ }^{45}$-, el gesto francfortiano espera introducir en tal unidad idéntica su otreidad: «lo completamente otro», lo llama Horkheimer ${ }^{46}$. Esa otreidad es el ideal de una razón autónoma que es innombrable, porque, en cuanto aquello que es lo otro de lo idéntico, es inconceptualizable. La Idea Regulativa se convierte, así, en una especie de todo y nada simultáneos, en presencia despresente. Está presente porque la falsedad del todo social la demanda desde sí, expresándose en el pensador como un anhelo. Está ausente, porque carece de nombre y contenido y es sólo un «color imborrable» ${ }^{47}$. El tono mesiánico y cabalístico hacen de este nuevo deus absconditus el punto de mira desde el que se descifra el mundo, trastocándolo mediante la crítica negativa, que ha de mostrar, en el ámbito social identitario, su no-identidad ${ }^{48}$. En la Escuela de Francfort, pues, es detectable el operador barroco. Ahora bien, el infinito aporético aspirado e inalcanzable contiene todavía en su claroscuro la añoranza de una reconciliación al estilo ilustrado, como ha mostrado A. Wellmer ${ }^{49}$. Es el hundimiento de las Ideas kantianas de la razón -que expresan la unidad de todo lo particular en un todo sintético- lo que genera la crítica al pensamiento identitario. Y, por ello, contiene, a contraluz, la esperanza utópica de reinstaurar, aunque ello sea imposible, una unidad sintética, una «síntesis sin coerciones» ${ }^{50}$. En el subsuelo de este pensamiento es limitada -a nuestro juicio- la figura barroca de una infinita diferencia aporética por la de una imposible unidad de lo múltiple. En la siguiente generación francfortiana, representada por K.-O. Apel y J. Habermas, la sombra barroca es ya completamente rechazada. El ausente despresente de lo anhelado es sustituido ahora por la luz de una comunidad ideal e ilimitada de comunicación, que es el nuevo ideal regulativo para una aproximación infinita y asintótica de la racionalidad. Conducidos los fragmentos dialógico-argumentativos de la facticidad a semejante ideal, sus diferencias son contempladas, tal y como hemos intentado mostrar en otros lugares ${ }^{51}$, bajo el prisma de una reunión total, imposible por contrafáctica, pero inscrita como un resorte de progreso en un devenir inacabable del mundo socio-político y cultural.

A partir del estructuralismo de los años 60 es cuando la sombra del neobarroco se extiende prácticamente a todo el territorio de autoexperiencia humana y de interpretación filosófica. Ahora bien, como hemos señalado, surgen dos líneas que se bifurcan, la de una postmodernidad débil y la de una trans-modernidad fuerte. Las dos, a nuestro juicio, emergen -no sólo pero ante todo- en un intento de trascender el mundo de la fenomenología existencial, especialmente el de M. Heidegger. La primera de ellas desvanece el último residuo de normatividad que se encontraba en el movimiento heideggeriano. Pues en éste tienen lugar dos procesos correlativos. Por

45 «La contradicción es lo no idéntico bajo el aspecto de la identidad (...) La totalidad de la contradicción no es más que la falsedad de la identificación total, tal y como se manifiesta en ésta. Contradicción es no-identidad bajo el conjuro de la ley que afecta también a lo no-idéntico» (Adorno, Th. W. Dialéctica negativa, op. cit., pp. 14-15).

46 Horkheimer, M. «La añoranza de lo completamente otro», en Marcuse/otros, A la búsqueda del sentido. Salamanca, Sígueme, 1976, pp. 67-124.

47 Adorno, Th. W. Dialéctica negativa, op. cit., p. 62.

48 «El único modo que aún le queda a la filosofía de responsabilizarse a la vista de la desesperación es intentar ver las cosas tal como aparecen desde la perspectiva de la redención (...) Es preciso fijar perspectivas en las que el mundo aparezca trastocado, enajenado, mostrando su grietas y desgarros» (Adorno, Th. W. Minima Moralia. Caracas, Monte Ávila, 1975, p. 250).

49 Cfr. Wellmer, A. Finales de partida: la modernidad irreconciliable. Madrid, Cátedra, 1996, caps. 6 y 8.

$50 \quad$ Ibid., p. 249.

51 V. Sáez Rueda, L. «¿Es posible una razón crítica sin recurso a Ideas Regulativas? -El nexo entre las dimensiones reflexiva y existencial de la crítica de patologías». Isegoría, no 26 (2002), pp. 257-275. También Ser errático. Una ontología crítica de la sociedad, op. cit., cap. $9, \S 2$. 
un lado, la visión de nuestro mundo es ya plenamente atravesada por la diferencia. En este sentido, es radicalizada la posición francfortiana. Lo infinito aporético y diferencial ya no está visto desde esa trascendencia desde dentro que es la Idea Regulativa en su claroscuro. Heidegger pone en juego una auto-trascendencia sin regulación ideal. La inmanencia de lo que llamamos «real» es aquí radical, pues la diferencia óntico-ontológica que atraviesa a la identidad se erige, sin otro recurso, en potencia de la auto-diferenciación del mundo, histórica y culturalmente. Por otro lado, sin embargo, aparece un nuevo modo de discernir y distinguir entre lo digno y lo indigno. El nihilismo propio hace comparecer, de nuevo, un claroscuro: la copertenencia entre el ser y la nada, siendo esta última la ausencia de fundamento del primero y, ante todo, su ocultamiento en el mismo movimiento por el cual se desencubre. Este nihilismo contiene la afirmación de un criterio para la existencia del hombre: la escucha de este ser presente y ausente al unísono, pues él llama o demanda al existente, al $D a-s e i n$, hacia la toma de partida por una dirección en su discurrir. Y no es Una dirección, por supuesto, no es unívoca y dirigida a un todo aglomerante: es la dirección hacia lo que el ser reclama en su auto-mutación infinita, sólo explicitable en una multiplicidad de modos posibles. El nihilismo impropio, por el contrario, renuncia testarudamente a la escucha, olvida el ser y se decanta por la reducción de éste al desierto espectral de lo no-más-que-ente. Por este camino el hombre se extravía, sin dirección, en la errancia, en un laberinto de andanzas que se dispersan en mil figuras, tan diferentes entre sí como pueden ser las improvisaciones de una imaginación des-quiciada, pero afirmadas sobre lo Mismo: el desarraigo respecto al habitar el mundo y su concomitante empeño humano por hacerse dueño y señor de todo lo existente ${ }^{52}$. El nihil activo y normativo del nihilismo propio es diluido, en el impropio, por esta multívoca «errancia, en la que se expande el vacío» ${ }^{53}$. La errancia, expresable en una multiplicidad de formas y por muy prolífica que parezca por ello, sólo organiza ese vacío completamente carencial ${ }^{54}$.

No se puede decir que Heidegger atraiga al Barroco hacia su pensamiento, pues a pesar de esos reflejos que se especifican en el claroscuro de la presenciadespresente del ser falta, en el desfallecido mundo del olvido del ser, el trabajo de lo aporético, que concierne a la inclusión invertida de los otros puntos de vista en el cada uno de los singulares: lo aquí contemplado, en el nihilismo impropio, es un desierto unánime, omniabarcante, que lo convierte a todo en igualdad: la errancia posee multitud de diferencias, pero todas remiten a un mismo y comprehensivo horizonte de sentido. Y el nihilismo propio, desde el que se mira, es como un nuevo absconditus, un ser-nada en claroscuro, sí, pero presto a expresarse luminosamente en una multiplicidad de mundos de sentido abiertos, des-encubiertos, cada uno de los cuales posee su propia habitabilidad interna. Ahora bien, esta pálida y menguada sombra de lo barroco en la comprensión heideggeriana del mundo hace estallar, como contra-golpe, un neobarroco próximo a nosotros. El débil es el que destituye incluso al ser que se encubre en su venida a presencia y, por tanto, a la secreta dirección apelativa que propicia desde este postrero absconditus. Adopta la forma de una errancia de los puntos de vista, sordos unos respecto a otros, afirmando cada uno su

52 Respecto a la distinción entre «nihilismo propio» y «nihilismo impropio» V. Heidegger, M. Nietzsche. Barcelona, Destino, 2000, II, pp. 287-293.

53 Heidegger, M. «Superación de la Metafísica», en Conferencias y artículos. Barcelona, Serbal, 1994, pp. 51-73, p. 71.

${ }_{54}$ Cfr. Ibid., p. 70. 
sutil centricidad. Constituye, no el desgarramiento de lo Idéntico por la entrada en su seno de la diferencia, sino su mera partición en minúsculas identidades proliferantes, con lo cual reduce la problematicidad del mundo a la de lo uno y lo múltiple. Este principio puede investirse metafóricamente de muchos atuendos o atavíos. Puede tratarse de esquirlas respecto a la madera, de lascas respecto a la piedra, de gotas o flujos respecto al océano... En cualquier caso, ya no señalan diferencialmente a un infinito aporéticamente asistente en la forma de su propia fuga, sino que desfibran, cuartean, licúan, etc. un Uno que alguna vez tuvo límites y periferia a pesar de su inmensidad. Se conectan, por lo demás, ya en aglomeración vibrátil, ya en cruce o en dispersión, pero siempre rehuyendo una nueva normatividad naciente en sus relaciones. En definitiva: desplazan el antiguo Cosmos hacia el mero Caos. ¿No se ajustan a esta imagen genérica los rasgos neobarrocos que detecta Calabrese en el presente? Todos ellos afirman el resquebrajamiento del todo-uno, sea tendente al entrecruzamiento o a la dispersión ${ }^{55}$. El neobarroco fláccido es el que afirma el mundo cultural de los meros simulacros que degluten todo tipo de realidad pensable, descrito por Baudrillard ${ }^{56} \mathrm{o}$ el del mundo del espectáculo en mil máscaras del capitalismo tardío, que absorbe en la representación lo supuestamente representado, auscultado por Debord ${ }^{57}$. Es el de la muerte definitiva de los metarrelatos fotografiado por Lyotard ${ }^{58}$, el mundo líquido que flexibiliza subjetividades y procesos sociales sin ofrecerles paradero alguno, dibujado por Bauman en sus diversos textos sobre el tema. $\mathrm{O}$ es, por acabar aquí, el expresado por Sarduy desde un símil cosmológico, el de una nueva inestabilidad en virtud de la cual, a partir de ciertas condiciones de estabilidad primeras, el todo se desestabiliza, disgregándose en una multitud de galaxias que se alejan entre sí sin orden o concierto ${ }^{59}$. Las corrientes filosóficas que siguen esta línea son, a nuestro entender, el pensamiento débil ${ }^{60}$ y el neopragmatismo americano, sobre todo este último. Rorty, que lo lidera, intenta «poner cabeza abajo» a Heidegger ${ }^{61}$. La multiplicidad sería un tejido relacional y relativista de mundos sociales «ya siempre abiertos», cada uno de los cuales es un conjunto de prácticas y hábitos susceptibles de ser descritos empíricamente, de modo naturalista ${ }^{62}$. Se trata siempre, en la postmodernidad débil, de sustituir el antiguo Cosmos, considerado como un todo, en una diversificación que tiene su sentido en la errancia a-normativa de sus fragmentos: del Cosmos al Caos.

55 Ritmo y repetición, exceso, fragmento, inestabilidad y metamorfosis, desorden o caos, laberinto, complejidad, «más o menos y no sé qué» y distorsión. Cfr. Calabrese, O. La era neobarroca. Madrid, Cátedra, 1989.

56 Baudrillard, J. Cultura y simulacro. Barcelona, Kairós, 1978.

57 Debord, G. La sociedad del espectáculo. Valencia, Pre-Textos, 1999.

58 Lyotard, J.-F. La condición posmoderna, Madrid, Cátedra, 1989.

59 Sarduy, S. «Nueva inestabilidad», en Ensayos generales sobre el barroco. México-Buenos Aires, F.C.E., 1987, pp. 9-52.

60 Se trata, como se sabe, del movimiento que impulsó G. Vattimo. Vattimo recusa explícitamente la diferencia óntico-ontológica heideggeriana, con el propósito de debilitar las categorías fuertes de la hermenéutica. En tal proyecto, el acontecimiento del ser es reducido al mero «suceder» de lo efímero, a la, «trans-misión descolorida, acumulación de rasgos 'arqueológicos'» (Vattimo/otros, El pensamiento débil. Madrid, Cátedra, 1990, p. 30).

${ }_{61}$ Rorty, R. Contingencia. Ironía y Solidaridad. Barcelona, Paidós, 1991, p. 135.

62 V. Rorty, R. «Wittgenstein, Heidegger und die Hypostasierung der Sprache», en McGuinnes, B. (ed.), Der Löwe spricht...und wir können ihn nicht verstehen. Frankfurt a. M., Suhrkamp, 1991, pp. 69-93. 


\section{El Caosmos en la diferencia aporética infinita. Transmodernidad fuerte}

El retorno de lo barroco no puede ser entendido simplemente al modo de la postmodernidad débil, pues a su través es desvitalizado. Y es que le pertenece al Barroco una normatividad precisa y sutil que le permite incidir en el mundo de manera heroica y con tintes trágicos. Es la trans-modernidad fuerte la que recoge hoy ese pathos comprometido y transgresor. Pero antes quisiéramos mostrar el modo en que esta línea intenta trascender el mundo heideggeriano manteniendo la figura de la diferencia aporética infinita. Ello se realiza -a nuestro juicio-imprimiéndole a tal figura de pensamiento el carácter del Caosmos. Entendemos el gesto caosmótico como aquel que dispone las diferencias en torno a un infinito despresente que las vincula en un movimiento autopoiético y que abre una nueva normatividad, ni ilustrada ni fenomenológica, en su seno. Aparece expresamente en pocas ocasiones, pero nos parece que in-siste como un impensado en todas sus formulaciones, de las cuales seleccionaremos las que nos parecen hoy más significativas.

En el caso del postestructuralismo francés la controversia con Heidegger es más evidente. Se trata ahí de trascender el resto de pensamiento identitario heideggeriano. El ser, en el pensador alemán, es diferencia óntico-ontológica, sí, pero ésta es aprehendida como una mismidad que permanece en todos los mundos de sentido que, por mor de ella, son abiertos histórica o culturalmente ${ }^{63}$. Foucault pone en juego la figura de lo reticular. El mundo humano es un movimiento inacabable y proteico de fuerzas que se cruzan afectándose recíprocamente y en litigio. Los acontecimientos, en tal paisaje, ya no remiten a una mismidad, sino que habitan en el intersticio de tales fuerzas. Continuamente auto-diferenciándose, son aporéticos en la medida en que emergen en el «entre» de las diferencias, que es un «no lugar, una pura distancia» ${ }^{64}$, es decir, un nihil activo que reintroduce, sin que el propio autor lo exprese, el juego de la presencia y de la ausencia barroco. Lo caosmótico está aquí supuesto o impensado: ese mundo reticular se hace a sí mismo. Ello está implícito en la noción foucaultiana de intencionalidad asubjetiva ${ }^{65}$ : en la red son depositadas intencionalidades humanas concretas, pero todas y cada una de ellas se pierden finalmente en las inter-afecciones, que engendran un auto-movimiento cualitativamente mayor que la suma completa. No se trata de un Cosmos, pero tampoco de un Caos, a nuestro juicio: el entramado de intersticios no es arbitrario; su contingencia encuentra un límite en esta extraña normatividad interna de lo reticular; ante el afectar de una fuerza caben muchas posibilidades de afección desde las otras,

63 Heidegger se refiere al Ser en ese sentido. «El ser sólo esencia como único, mientras que por el contrario el ente es, según el caso, éste o aquel, tal cosa y no la otra. (...) [El ser] constantemente es, en tanto que lo único, lo Mismo (das Selbe). En tanto que eso Mismo, no excluye lo diferente» (Heidegger, M. Conceptos fundamentales (Curso del semestre de verano, Friburgo, 1941). Madrid, Alianza, 1994, pp. 110-111). La mismidad del ser aparece también en la íntima estructura de la diferencia. El ser qua diferencia es un entre que reúne y separa dos momentos, el de su sobrevenida desencubridora del sentido del ente y el de su llegada a éste, en la que se oculta. En tal sentido es lo Mismo articulador, copertenencia recíproca de lo diferente (Cfr.. Heidegger, M. «La constitución onto-teo-lógica de la metafísica», en Identidad y diferencia, op. cit., pp. 139-141). A la homología de lo diferente se une la interioridad del lazo: el «estar fuera» de la existencia (Da-sein) es interpretado por Heidegger como instancia (Inständigkeit), un estar dentro del horizonte del ser (Heidegger, M. «Introducción a ¿Qué es Metafísica?’», en Hitos. Madrid, Alianza, 2000, pp. 299-312, p. 306).

64 Foucault, M. «Nietzsche, la genealogía, la historia», en Microfísica del poder. Madrid, La Piqueta, 1991, p. 16. Cfr. pp. 13-18.

${ }^{65}$ Cfr. Foucault, M. La voluntad de saber. Madrid, Siglo XXI, 1998, pp. 115 y ss. 
pero no cualquiera: ha de ser una que precisamente surja del ser afectado y que sea capaz de afectar.

En Derrida es disuelto el Mismo heideggeriano de otro modo, introduciendo la figura de la diseminación, la cual es comprendida desde las de la denegación y de la promesa infinitas. Expresado de una forma sucinta, lo que Derrida le reprocha a Heidegger es que el advenimiento del ser abra (des-encubra en su encubrimiento) «horizontes de sentido» diferentes, cada uno de los cuales es un mundo englobante habitable, lo cual implicaría una mismidad, una filía entre el venir a presencia y la presencia. Ello es imposible, según el francés, porque tal advenimiento del ser, como acontecimiento, es aporético: es siempre colapsado en el ámbito óntico, fáctico. Su potencia des-encubridora es denegada por éste, de manera que jamás podrá imprimirle un sentido englobante en un contexto temporal o cultural, una comprensión concreta del mundo abierta. Toda experiencia es, pues, huella, la presencia de una despresencia. Esta reticencia a la luminosidad de cada uno de los diferentes mundos implica que la expresión del sentido sea diferida sin cese, convirtiéndose en una promesa infinita ${ }^{66}$ que atraviesa, desde su secreto, todo ad-venir y que al unísono impide cualquier advenir singular como marco de sentido. Pues bien, el gesto caosmótico se muestra en esta versión del postestructuralismo, según nuestro parecer, en que la denegación del sentido - este nuevo rostro de lo presente-ausente del mundo- lo disemina, es decir, lo sitúa en el entre de los contextos a los que lo hace diferir. Pero tal diseminación no opera en un puro juego de azar o arbitrio, sino imantado por la extraña pero eficiente normatividad de la promesa infinita -otro rostro inmanente del infinito absconditus-.

La impronta de lo caosmótico en la diferencia aporética infinita aparece ya explícitamente en G. Deleuze, bajo la figura del rizoma. Deleuze pretende, de modo expreso, proseguir la «intuición heideggeriana», es decir, la de relacionar lo diferente, pero eliminando la mismidad que subyace a esa intuición ${ }^{67}$. Y transita por ese camino intensificando lo que, a nuestro parecer, operaría en su pensamiento como intuición foucaultiana. El entre o intersticio es ahora conducido desde la figura de la retícula a la del rizoma. Se pregunta cómo es posible que las fuerzas se afecten entre sí. Su respuesta es la siguiente. En una síntesis disyuntiva, la unidad mínima del rizoma, dos fuerzas se diferencian recíprocamente. Cada una de ellas afecta a la otra y genera en ella una diferenciación, de manera que ambas devienen auto-transfigurándose como en una historia embrollada. Tal autotransfiguración se produce por mor de la diferencia misma entre ellas, su intersticio. Este no lugar es el diferenciante, el propulsor de la síntesis disyuntiva, al que llama también precursor oscuro -pues a cada paso de la relación invoca una nueva diferencia entre las fuerzas-e instancia paradójica: es y no es a un tiempo (es en la medida en que promueve la diferenciación,

${ }_{66}$ Cfr. Derrida, J. «La palabra soplada», en La escritura y la diferencia. Barcelona, Anthropos, 1989. De un modo más expreso, esta aporética de la denegación aparece en Derrida, J., «Cómo no hablar. Denegaciones». Suplementos Anthropos, no 13 (1989), pp. 3-35. El carácter denegador inherente al sentido deriva de su fuerza de ruptura con cualquier contexto (V. Derrida, J., «Firma, acontecimiento, contexto», en Márgenes de la Filosofía. Madrid, Cátedra, 1989, pp. 347-370). Gran parte de la confrontación con Heidegger se encuentra en Derrida, J. Del espíritu. Heidegger y la pregunta. Valencia, Pre-Textos, 1989, pero un resumen especialmente iluminador aparece en «Autoinmunidad: suicidios simbólicos y reales. Diálogo con Jacques Derrida» (Octubre de 2001), en Borradori, G. (ed.), La filosofía en una época de terror. Diálogos con J. Habermas y J. Derrida. Madrid, Taurus, 2003, pp. 131-135: entre la venida a presencia del sentido y la presencia habría una inapropiación, responsable de que el sentido fracase en su presentación misma.

${ }^{67}$ Deleuze, G. Diferencia y Repetición. Madrid, Ed. Júcar, 1988, pp. 32 y ss., 132 y ss., 203 y ss., 470 y ss. 
no es porque es un nihil activo; ninguna de las fuerzas, sino su ligazón relacional) ${ }^{68}$. El rizoma es un conjunto profuso de síntesis disyuntivas que realizan, a su vez, síntesis disyuntivas entre sí. Pues bien, deviene infinitamente, pero, una vez más, no de modo arbitrario. Posee una infinitud en su textura porque la inter-relación de las fuerzas es concebida al modo nietzscheano, es decir, como impelidas por un exceso o exuberancia que radica en el impulso hacia la intensificación afirmativa de la vida, una vida que tiende a más vida, a mayor riqueza de formas en su auto-creadora expansión ${ }^{69}$. Al mismo tiempo, surge aquí una insólita forma de normatividad, la del diferenciante de los diferenciantes o, visto aporéticamente, la de la instancia paradójica de la multiplicidad de instancias paradójicas. Tal instancia normativa, y dado que el rizoma se auto-altera en su devenir, está en todos los intersticios disyuntivos y en ninguno en particular. Es un presente-despresente que circula en el complejo rizomático sin convertirse jamás en una presencia $\mathrm{y}$, manteniéndose como hemos defendido en otro lugar-in status nascendi $i^{70}$. Se trata, en la caósmosis, de un «orden nómada» por el cual la auto-generación de la diferencia rizomática mantiene una reglamentariedad por endoconsistencia ${ }^{71}$, tal y como las diferentes intervenciones instrumentales, conducidas por una oscura y paradójica pauta autoalterante, mantendrían su consistencia interna en el jazz. Es así como se organizarían los puntos de vista y las diferencias aporéticas en el Barroco, según Deleuze, siendo la clave del Neobarroco una ruptura con la armonía preestablecida leibnizeana que transforma la monadología en una nomadología ${ }^{72}$.

La impronta caosmótica en el Neobarroco puede ser reconocida, aunque no esté explícita, en una gran variedad de formulaciones actuales, en su fondo, como una tendencia no reconocida que pugna por ser tematizada. En cualquier caso, siempre se trata de inmanentizar el infinito absconditus del XVII, convirtiéndolo en una presencia-despresente que es señalada o aludida (porque es indecible) por las diferencias entre sentidos o fuerzas, dispuestas reticularmente, en diseminación o en pliegue. Aparece en una nueva sensibilidad estética, descrita por Buci-Glucksmann, basada en la proliferación del entre-dos en un infinito drapeado ${ }^{73}$ y ofreciendo, así, una «lección estética y ética que implica, sin duda, esta transmutación de la pesadez en ligereza que quería Nietzsche y este 'coraje de la superficie'» ${ }^{74}$. Esta nueva sensibilidad estética introduce el pensamiento filosófico en formas artísticas, para ocluir el concepto unívoco y rodearlo, indescifrable, por multitud de desciframientos que lo aluden a través de la magia de las palabras o las imágenes. Cobra relevancia en este punto todo un pensamiento del Sur, iberolatinoamericano. Lo retrató Sarduy de

68 Cfr., por ejemplo, Deleuze, G. Diferencia y repetición, op. cit. p. 206 y ss.; Lógica del sentido. Barcelona, Paidós, 1989, pp. 69 y ss.

69 La «voluntad de poder» en Nietzsche es entendida por Deleuze, incluso, como el diferenciante de las fuerzas. Cfr. Deleuze, G. Nietzsche y la filosofia. Barcelona, Anagrama, 1994, pp. 90 y ss.

70 Sáez Rueda, L. El ocaso de Occidente. Barcelona, Herder, 2015, pp. 84-104.

71 Cfr. Deleuze, G./Guattari, F. Mil Mesetas. Capitalismo y esquizofrenia. Valencia, Pre-textos, 1998, pp. $381-391$. Para la noción de endoconsistencia resulta esclarecedora toda la Introducción («Rizoma»).

72 Cfr. Deleuze, G. El pliegue, op. cit., cap. 9.

73 Es la que sitúa la mirada en un tipo de ornamentación dinamizada por el claroscuro del entre-dos, del entremundos o del entre-imágenes, intersticios proliferantes que suponen una secreta e inaccesible virtualidad sólo visibilizada indirectamente a su través, «testimoniando las artes nómadas y bárbaras, con sus líneas-flujo en ribetes, espirales y zigzags, como en la vida» (Buci-Glucksmann, Chr. Philosophie de l'ornement. París, Galilée, 2008, p. 26. V. pp. 163-181). Como ejemplo, ofrece la autora el ideal del drapeado al que se refirió F. García Lorca (p. 25).

74 Buci-Glucksmann, Chr. Esthétique de l'ephémère. París, Galilée, 2003, p. 85. V. pp. 67-85. 
forma difícilmente superable. Se trata de un arte pensante que alude, señala, etc., lo infinito o plenitud ausente e indecible por medio de estrategias como la «sustitución» -que escamotea el significado correspondiente a un significante, sustituyendo a este último por otros en un encadenamiento que no encuentra término esencial-, la «proliferación»-que opera por acumulación de significantes que remiten unos a otros y que rodean al significante ausente, trazando una órbita alrededor de él, connotándolo sin nombrarlo, como si señalase al expulsado, al que ostenta las huellas del exilio- o la «condensación»-que reúne dos términos que chocan entre sí en un tercero, como en amosclavo o maquinoscrito, obliterando un significado innombrable ${ }^{75}$. Esta textura del Neobarroco latinoamericano se expresa de modos diferentes, pero siempre tomando el esbozo que acabamos de hacer para llevarlo a modalidades que expresan también la mixtura, la carnavalización y la huella de un origen en claroscuro tras la colonización ${ }^{76}$.

\section{La experiencia del desengaño y el héroe barroco, transgresor en el mundo}

La normatividad en la que se incrusta el nuevo barroco no pertenece sólo a la visión del mundo que proporciona, sino también a la peculiaridad del hombre barroco en cuanto héroe que incide en el mundo. Crucial en este punto es poner de manifiesto la experiencia barroca del desengaño. El hombre del XVII es un ser que, por la inversión del mundo y por la huida del absoluto, vive profundamente el desengaño. Pero éste se convierte en un acicate, impulsa a un desciframiento del desorden del mundo bajo su apariencia ordenada e impele, a través de una especie de desesperación activa, hacia una praxis a contragolpe del desencanto, como si pusiese en obra ese principio del hombre trágico que fascinó a K. Jaspers: el de enfrentarse a la universalización de un orden perverso y convertirse, por ello, en un héroe que triunfa en su caída ${ }^{77}$. Este tipo de héroe, como dilucida Díaz-Plaja, surge precisamente en una época en la que la heroicidad ha huido del ámbito público, de la gran política y del espejo de ésta en la gesta militar, lo que explica que ésta se aloje en el deslumbrante ámbito de las letras en esta época, en las que predomina una épica del hombre enfrentado a la gobernanza objetiva, solitariamente defraudado, condenado por el pragmatismo y la falta de ideales de su realidad envolvente ${ }^{78}$. Es por esto por lo que nos resulta equivocado el punto de vista de Maravall, quien, a pesar de ensalzar la enorme riqueza de nuestro Siglo de Oro, suele vincular lo heroico del Barroco más con una afirmación de sí frente al otro que con la defensa de lo grandioso humano, subrayando en la visión del mundo de esta época, y como consecuencia de la crisis, la actitud del homo homini lupus hobbesiano ${ }^{79}$ y sentenciando que «la constante referencia al desengaño (...) produjo una común disposición para buscar el bien propio a costa del ajeno (...)

75 Cfr. Sarduy, S. "El Barroco y el Neobarroco", en Fernández Moreno, C. (coord.). América Latina en su literatura. México-París, Siglo XXI/Unesco, 1972, pp. 167-184.

76 Figuras importantes son José Lezama Lima, Alejo Carpentier, Haroldo de Campos, Octavio Paz, Roberto Echavarren o Néstor Perlonher. Para una actualización de esta problemática V. Rossi, M. J., «Cartografías del barroco en América Latina». Ekstasis. Revista de hermenêutica e fenomenologia, Vol. 5, nº 1 (2016), pp. 91-121.

77 Jaspers, K. «Lo trágico», en Lo trágico. El lenguaje. Granada, Ágora, 1995, p. 64; cfr. pp. 61-64).

78 Cf. Díaz-Plaja, G. El espíritu del Barroco. Barcelona, Crítica, 1983, primera parte.

79 Cfr. Maravall, J.A. La cultura del barroco. Barcelona, Ariel, 1990, capítulo VI., donde describe el sentimiento de lucha de todos contra todos y hasta cierta misantropía que se extiende en Europa. 
[El desengaño significa] adecuación a un mundo que es transitorio y aparente» ${ }^{80}$. Efectivamente, es clave central del Barroco la decepción que hace prácticamente indiscernibles la verdad y la apariencia, pues lo absoluto se ha retirado. De ahí que el lema calderoniano de la vida como sueño pueda ser generalizado en este período como un sentir modulado de diversas formas. Ahora bien, derrumbado el Todo-Uno pre-moderno, la unidad de lo justo, lo verdadero y lo bello es transmutada en un ideal de trascendencia que contrasta con el desastre de lo finito, convirtiéndose en un infinito apelado, invocado, anhelado. Adopta así tintes trágicos: «en el naufragio de lo finito contempla el hombre la realidad y la verdad de lo infinito» ${ }^{81}$. Y el héroe barroco intentará mirar al mundo desde esa apelación a lo necesario-imposible para convulsionar el orden existente. Tres modelos de heroísmo, al menos, podríamos discernir. El primero es, precisamente, el calderoniano, tan admirado por Benjamin y al que llamaremos «satírico». En el drama del mundo sumido en la apariencia onírica este heroísmo se apropia de la trascendencia de un modo lúdico y por rodeos y, por inclusión indirecta en lo mundano, «como por medio de un espejo, o de un cristal o un teatro de marionetas», inserta una infinitud reflexiva, determinante de que, de un modo o de otro «tendrá jurisdicción precisamente la moralidad» ${ }^{82}$. Uno de los efectos críticos de este modelo afecta a la soberanía. Es en el Barroco cuando, propiamente, según C. Schmitt, la cuestión de la soberanía se desarrolla en torno al problema del estado de excepción, que el príncipe ha de subsanar a toda costa mediante la decisión ${ }^{83}$. En esta situación, el ingenio barroco español, por una parte, inviste al príncipe de poderes divinos, mientras que, por otra, presenta irónicamente su desmesura, su crueldad o su pusilanimidad, todo aquello que muestra su incompetencia, precisamente, para decidir; con ello se lo sitúa en el seno de la vulnerabilidad de lo humano y se lo juzga indirectamente, a menudo presentándolo de forma veladamente grotesca ${ }^{84}$. El segundo modelo de heroísmo desengañado es el que llamaríamos «des-quiciamiento excéntrico», que encuentra su ejemplar manifestación en la figura de D. Quijote, este personaje que se adelanta a su época entrando genialmente en lo barroco. Es barroco su desengaño porque se mantiene continuamente ante la experiencia del fracaso de su ideal entusiasta en un mundo que se resiste a ser transformado, al mismo tiempo que denuncia las apariencias, en cuyo seno medran la maldad, el embuste o la bellaquería, dispuestas como una ficción organizada. El desengaño es una cura del héroe, porque surge lúcida y melancólicamente después de tocar las apariencias con su propia mano ${ }^{85}$. Pero es, al unísono, una intervención en la praxis que des-quicia, desde ese desquiciamiento de la locura, todo lo que toca, desvelando su vileza cubierta por la apariencia. Al abandonar su ensimismada centricidad en la hacienda, D. Quijote elige un devenir ex-céntrico, que lo mantiene constantemente en el límite del mundo, o mejor, en el entre o intersticio de la multiplicidad de mundos que atraviesa. Sólo en el paso mismo de una estancia a otra encuentra cierta

$80 \quad$ Ibid, p. 415.

81 Jaspers, K. «lo trágico», loc. cit., p. 88.

82 Benjamin, W. El origen del 'Trauerspiel'alemán, op. cit., p. 286. Cfr. pp. 286-293. Benjamin cita como texto ejemplar el siguiente: «Mas, sea verdad o sueño, obrar bien es lo que importa. Si fuese verdad, por serlo; si no, por ganar amigos para cuando despertemos» (Calderón de la Barca, P. La vida es sueño, en Obras Completas. Madrid, Aguilar, 1987, p. 525).

83 Schmitt, C., Teología política. Madrid, Trotta, 2009, pp. 16 y ss. y 75 y ss.

${ }^{84}$ Cfr. Benjamin, W. op. cit., pp. 268-293.

85 Cfr. Cerezo, P. El Quijote y la aventura de la libertad. Madrid, Biblioteca Nueva, 2016, pp. 312-321. 
paz, en el camino en cuanto tal. Y allí donde se aloja, en el albergue de un grupo de cabreros o en una posada cualquiera, disloca la intimidad de su entraña mediante la extrañeza que él mismo encarna. Él es, en cada mundo concreto, el testimonio vivo de lo ex-céntrico y, por eso, rompe el quicio de la centricidad en la que penetra, trascendiéndola y transgrediendo la interna y aparente coherencia de su sentido. Una mirada quijotesca es, a nuestro juicio, siempre una intervención excéntrica, muestra lo otro del sentido sin lo cual éste no podría ser lo que es. Si llega, por ejemplo, a una taberna y el caballero de la Triste Figura trata a unas mujeres que son allí tomadas por toscas -y envilecidas por ello- como a doncellas o damas, no está simplemente reinterpretando, sino dis-locando el sentido. Y pone así, al mismo tiempo, al descubierto su sinsentido inmanente, humillándolo ${ }^{86}$. El tercer modelo al que nos referiremos es el del «héroe de luto», representado por la actitud del jesuita de la Contrarreforma, cuyo desencanto es frío y prudencial, dirigido al poder, sobre el mundo de la cultura y sobre sí mismo simultáneamente, una facultad que, como aprecia inteligentemente Benjamin, «exige tanto rigurosa disciplina interna como la acción más inescrupulosa hacia el exterior», lo que «suscita el luto en la criatura que ha sido despojada de todo impulso ingenuo ${ }^{87}$. Es el de Gracián (al que se refiere el pasaje benjaminiano) el que encarna este héroe. $\mathrm{Su}$ pesimismo no predica la resignación, el ascetismo o la negación de la vida, sino la vida fuerte. El héroe graciano es mixto y contradictorio, actúa siempre en los dos mundos, en el mundo pragmático y en el de la virtud ${ }^{88}$. Interviene en el mundo estratégicamente, de forma calculadora ${ }^{89}$ y hasta con cierto maquiavelismo ${ }^{90}$. Ahora bien, el desengaño introduce también el infinito de la trascendencia (que está en huida), procurando la entereza, que no se aviene con una actitud acomodaticia ${ }^{91}$ y que sería la sustancia de la vida heroica, porque no se aviene con una actitud acomodaticia y táctica. Y como ha mostrado P. Cerezo, representa en Gracián el todo íntegro de la virtud -una virtud que incluye la bondad, la sabiduría y la salud- y la protección del valor activo del desengaño. «Entereza también frente al desengaño, para no abandonarse a la desesperación o al quietismo, sino integrarlo en una actitud heroica de lucha ${ }^{92}$.

86 Hemos reflexionado sobre lo heroico quijotesco en Sáez Rueda, L. Ser errático. Una ontología crítica de la sociedad. Madrid, Trotta, 2009, pp. 82-89 y en «Devenir excéntrico. Por una hermenéutica del entreclaro errático y de la dis-locación», en Adrian, B./Luciano, M. (eds.). Actas de las II Jornadas de hermenéutica. La hermenéutica en diálogo con la ciencias humanas y sociales: convergencias, contraposiciones y tensiones. Buenos Aires, Ediciones Proyecto Hermenéutica, 2012, pp. 11-25.

87 Benjamin, W. El origen del 'Trauerspiel' alemán, op. cit., p. 305.

88 «Todo Héroe participó tanto de felicidad y de grandeza, cuanto de virtud, porque corren paralelas desde el nacer al morir» (Gracián, B. El héroe. Barcelona, Estrategia Local, 2001, prim. últ., p. 127).

89 Lo que se expresa, por ejemplo, en esta sentencia: «Quando no puede uno vestirse la piel del león, vístase la de la Vulpeja. (...) Más cosas ha obrado la maña que la fuerça, y más vezes vencieron los Sabios a los valientes que al contrario. Quando no se puede alcançar la cosa, entra el desprecio» (Gracián, B. Oráculo Manual y arte de prudencia. Madrid, Cátedra, 1997, 220). Como sentencia con finura José Luis Villacañas, «Su milicia contra la malicia del mundo no invoca la huida. Su insistencia en que son pocos los que hacen buena guerra pende de su voluntad de combatir el mundo con las armas del mundo» (Villacañas, J. L.. «Gracián en el paisaje filosófico alemán. Una lectura desde Walter Benjamin, Arthur Schopenhauer y Hans Blumenberg», en Grande, M./Pinilla, R. (eds.). Gracián: Barroco y modernidad. Madrid, Univ. Pontif. de Comillas, 2004, pp. 283-306, p. 293-4).

90 «Todo lo dora un buen fin, aunque lo desmientan los desaciertos de los medios. Que es arte ir contra el arte quando no se puede de otro modo conseguir la dicha del salir bien» (Oráculo, op. cit., 66)

91 Pues «siempre el desengaño fue pasto de la prudencia, delicias de la entereza» (Ibid., 100). «Hombre de entereza. Siempre de parte de la razón, con tal tesón de su propósito, que ni la passión vulgar, ni la violencia tirana le obliguen jamás a pisar la raya de la razón» (Ibid, 29).

92 Cerezo, P. El héroe de luto, op. cit. p. 319, Cfr. pp. 314-320. 
En los diversos modos de la heroicidad desengañada el ingenio se convierte en la inteligencia de una sutil revuelta via negationis. Permite un contra agere aporético que pone en obra el dispositivo al que hemos llamado diferencia aporética infinita. La diferencia entre el mundo y lo infinito genera aporéticamente la negación del primero mediante la afirmación de la negatividad (retiro) del segundo. Ejemplar en esta actitud general del Barroco es el modus operandi graciano. En efecto, por un lado, el ingenio - a diferencia de la adivinatio renacentista, que permite descubrir la presencia de lo divino en las criaturas- propicia la insinuación de un absoluto ausente convertido en infinito ideal, pues su agudeza, que es su cualidad, hace ver la impostura del mundo y, así, a su través y como de reojo, la ausencia en él del orden retirado ${ }^{93}$. Por otro lado, y al unísono, tal insinuación de lo infinito ausente retroactúa obligando al mundo a medirse con él, como si estuviese agazapado y vigilante en el curso de los asuntos mundanos ${ }^{94}$.

Y bien, ¿podríamos hablar de una presencia de esta heroicidad barroca en su retorno actual? En la postmodernidad débil es evidente que no, pues sólo afirma la fragmentación del mundo sin incluir una normatividad. Pero, a nuestro juicio, sí en la trans-modernidad fuerte, a condición de que la consideremos como una aspiración tácita que se sitúa en lo impensado de lo pensado. Esa normatividad caosmótica a la que nos hemos referido aparece pálidamente aún en la Escuela de Francfort. Así, Adorno propone, como medio para aproximarse a lo No-Idéntico sin nombrarlo, la disposición de una constelación de conceptos que lo circundan y esquivan. En semejante proceder se vislumbra un rayo del gesto caosmótico; también la concomitante operación crítica consistente en señalar la no-identidad afirmándola a través de su negación por un rodeo sin cese ${ }^{95}$. Bajo la figura de lo reticular, Foucault, por ejemplo, intenta asimilar esa voluntad de «'heroizar' el presente» de Baudelaire: se trata de captar en lo fugitivo y contingente del presente, no simplemente la moda, sino lo permanente que se expresa en el movimiento perpetuo, con el fin de desafiarlo irónicamente. $\mathrm{Y}$ esto es lo que Foucault considera propio de una ontología de la actualidad: asir las condiciones que nos han hecho como somos para trascenderlas, negándolas y abriendo la frontera de una necesaria auto-invención novedosa, a través de una crítica permanente de nosotros mismos ${ }^{96}$. Bajo la figura de la diseminación, la deconstrucción derridiana encuentra siempre lo aporético de la experiencia y lo niega al mostrarlo, forzándolo así a auto-trascenderse via negationis en renovadas aporías criticables una y otra vez, haciendo comparecer la presenciadespresente de esa promesa infinita por imposible de la disolución de la aporía ${ }^{97}$.

93 Al respecto, V. De la Higuera, J., «El Barroco y nosotros. Perspectiva del Barroco desde la ontología de la actualidad», en Actas del Congreso Internacional Andalucía Barroca, Vol. IV (Ciencia, Filosofía, Religiosidad), Sevilla, Consejería de Cultura de la Junta de Andalucía, 2009, pp. 105-113, § 5.

94 García Gibert ve en este juego aporético del contra agere un «doble pliegue» (a la deleuzeana), por mor del cual se produce la reunión de lo ficticio y lo antificticio. En el ingenio «se alternan luz y oscuridad: el 'como si' de los medios divinos, convenientemente negado, contribuye a iluminar (desplegar) con su elíptico desplazamiento la realidad de los medios humanos; de inmediato, y, a la inversa, el 'como si no' de estos medios humanos despliega igualmente su foco a la realidad de los divinos» (Gibert, G. «Medios humanos y medios divinos en Baltasar Gracián». Criticón, nº 73, 1998, pp. 61-82, p. 69. Citado en Cerezo, P., El héroe de luto, op. cit., p. 145. V. también, «Del concepto de héroe al de persona», de Benito Pelegrín y «Un arte para el ingenio», de Jorge M. Ayala, en García Casanova, J. F., El mundo de Baltasar Gracián, Granada, Ed. Universidad de Granada, 2003.

95 Cfr. Adorno, Th. W. Dialéctica negativa, op. cit. pp. 65 y ss.

96 Cfr. Foucault, M. «¿Qué es Ilustración?», en Sobre la Ilustración. Madrid, Tecnos, 2003, pp. 81-94.

${ }_{97}$ Si se trata de la aporía de lo justo, por ejemplo -que hace de todo acto de justicia, mediante el derecho, una injusticia al caso singular, jamás subsumible bajo sus reglas- el momento deconstructor muestra el «sentido de 
Bajo la figura del rizoma, Deleuze entiende que el pensador está obligado a negar la necedad -la separación del pensamiento o de la acción respecto a la configuración problemático-caosmótica del mundo ${ }^{98}$-. Tal negación, que entristece, debe conducir a intervenir en tal realidad rizomática desde ella y en su infinito autotrasfigurador. El pensador ha de devenir, en la auto-generación caosmótica, aquello que piensa para convertirse en una fuerza diferenciadora más ${ }^{99}$. En cuanto al gesto caosmótico del Barroco iberoamericano, incluye una incursión revolucionaria en el mundo. En un doble pliegue -diríamos- se metamorfosea en su invasor o contrario, para, reduplicadamente, realizar una metamorfosis en él que lo devora. Es la operación de una «codigofagia» ${ }^{100} \mathrm{o}$ de una «razón antropofágica» ${ }^{101}$.

\section{Referencias bibliográficas}

Adorno, Th. W. Dialéctica Negativa. Madrid, Taurus, 1986.

Adorno, Th. W. Minima Moralia. Caracas, Monte Ávila, 1975.

Baudrillard, J. Cultura y simulacro. Barcelona, Kairós, 1978.

Benjamin, W. El origen del 'Trauerspiel' alemán, en Obras Completas. Madrid, Abada, 2006, Libro I, Vol. I, pp. 217-459.

Benjamin, W. Angelus Novus. Barcelona, Edhasa, 1966.

Blumenberg, H. La legitimación de la Edad Moderna. Valencia, Pre-Textos, 2008.

Buci-Glucksmann, Chr. Philosophie de l'ornement. París, Galilée, 2008.

Buci-Glucksmann, Chr. Esthétique de l'ephémère, París, Galilée, 2003.

Buci-Glucksmann, Chr. La folie du voir. Une esthétique du virtuel. París, Galilée, 2002.

Buci-Glucksmann, Chr. «La manera o el nacimiento de la estética», en Jarauta, F., BuciGlucksmann, Ch. (eds.). Barroco y Neobarroco. Madrid, Círculo de Bellas artes, 1992, pp. 23-33.

Calderón de la Barca, P. La vida es sueño, en Obras Completas. Madrid, Aguilar, 1987.

Campos, H. de. «Da razão antropofágica: a Europa sob o signo da devoração». Revista Colóquio-Letras, ${ }^{\circ} 62$ (1981), pp. 10-25.

Cerezo, P. El Quijote y la aventura de la libertad. Madrid, Biblioteca Nueva, 2016.

De la Higuera, J. «El Barroco y nosotros. Perspectiva del Barroco desde la ontología de la actualidad», en Actas del Congreso Internacional Andalucía Barroca. Vol. IV, Sevilla, Consejería de Cultura de la Junta de Andalucía, 2009, pp. 105-113.

una responsabilidad sin límite, y por tanto necesariamente excesiva» (Derrida, J. Fuerza de ley. Madrid, Tecnos, 1997, p. 45. Tal responsabilidad obliga a intentar decir lo indecible sin lograrlo.

98 La necedad es ese sinsentido de la autonomización del pensamiento respecto al mundo: «Se conocen pensamientos imbéciles, discursos imbéciles construidos totalmente a base de verdades; estas verdades son bajas, son las de un alma baja, pesada y de plomo. La estupidez y, más profundamente, aquello de lo que es sintoma: una manera baja de pensar» (Deleuze, G., Nietzsche y la filosofia, op. cit., pp. 148-149). Por eso «La filosofía sirve para entristecer. Una filosofía que no entristece o no contraría a nadie no es una filosofía. Sirve para detestar la estupidez» (Ibid., p. 149-150).

$99 \quad$ El filósofo deviene aquello ante lo que habla (por ejemplo, deviene indio), para que «el indio que es indio devenga él mismo algo más y se libere de su agonía. (...) El devenir siempre es doble, y este doble devenir es lo que constituye el pueblo venidero y la tierra nueva. La filosofía tiene que devenir no filosofía, para que la no filosofía devenga la tierra y el pueblo de la filosofía» (Deleuze, G./Guattari, F. ¿Qué es la filosofía? Barcelona, Anagrama, 1993, p. 111).

100 Cfr. Echeverría, B. La modernidad de lo barroco. México, Era, 1998, pp. 37 y ss.

101 Campos, H. de. «Da razão antropofágica: a Europa sob o signo da devoração». Revista Colóquio-Letras, ${ }^{\circ} 62$ (1981), pp. 10-25. 
Debord, G. La sociedad del espectáculo. Valencia, Pre-Textos, 1999.

Deleuze, G. (con Guattari, F.). Mil Mesetas. Capitalismo y esquizofrenia. Valencia, Pretextos, 1998.

Deleuze, G. Nietzsche y la filosofía. Barcelona, Anagrama, 1994.

Deleuze, G. (con Guattari, F.). ¿Qué es la filosofía? Barcelona, Anagrama, 1993.

Deleuze, G. El pliegue. Leibniz y el Barroco. Barcelona, Paidós, 1989.

Deleuze, G. Lógica del sentido. Barcelona, Paidós, 1989.

Deleuze, G. Diferencia y Repetición. Madrid, Ed. Júcar, 1988.

Derrida, J. «Autoinmunidad: suicidios simbólicos y reales. Diálogo con Jacques Derrida», en Borradori, G. (ed.). La filosofía en una época de terror. Diálogos con J. Habermas y J. Derrida. Madrid, Taurus, 2003, pp. 131-195.

Derrida, J. Fuerza de ley. Madrid, Tecnos, 1997.

Derrida, J. «La palabra soplada», en La escritura y la diferencia. Barcelona, Anthropos, 1989.

Derrida, J. «Cómo no hablar. Denegaciones». Suplementos Anthropos, nº 13 (1989), pp. 3-35.

Derrida, J. Del espíritu. Heidegger y la pregunta. Valencia, Pre-Textos, 1989.

Derrida, J. «Firma, acontecimiento, contexto», en Márgenes de la Filosofía. Madrid, Cátedra, 1989, pp. 347-370.

Díaz-Plaja, G. El espíritu del Barroco. Barcelona, Crítica, 1983.

Echeverría, J. «Leibniz: el Dios más barroco posible», en Jarauta, F., Buci-Glucksmann, Chr. Barroco y Neobarroco, op.cit., pp. 45-59.

Echeverría, J. La modernidad de lo barroco. México, Era, 1998.

Foucault, M. «¿Qué es Ilustración?», en Sobre la Ilustración. Madrid, Tecnos, 2003, pp. 7197.

Foucault, M. La voluntad de saber. Madrid, Siglo XXI, 1998.

Foucault, M. «Nietzsche, la genealogía, la historia», en Microfísica del poder. Madrid, La Piqueta, 1991.

Foucault, M. Microfisica del poder. Madrid, La Piqueta, 1991.

García Casanova, J. F. El mundo de Baltasar Gracián. Granada, Ed. Universidad de Granada, 2003.

Goldmann, L. El hombre y lo absoluto. El dios oculto, Barcelona, Península, 1985.

Gracián, B. El Criticón. Madrid, Cátedra, 2004.

Gracián, B. Oráculo Manual y arte de prudencia. Madrid, Cátedra, 1997.

Gracián, B. El héroe. Barcelona, Estrategia Local, 2001.

Habermas. J. Pensamiento postmetafísico. Madrid, Taurus, 1990.

Hauser, A. Historia social de la literatura y el arte. Barcelona, Labor, 1992.

Heidegger, M. Nietzsche. Barcelona, Destino, 2000.

Heidegger, M. Hitos. Madrid, Alianza, 2000.

Heidegger, M. Identidad y diferencia. Barcelona, Anthropos, 1990.

Heidegger, M. «Superación de la Metafísica», en Conferencias y artículos. Barcelona, Serbal, 1994.

Heidegger, M. «La pregunta por la técnica», en Conferencias y artículos. Barcelona, Serbal, 1994.

Heidegger, M. Conceptos fundamentales (Curso del semestre de verano, Friburgo, 1941). Madrid, Alianza, 1994.

Heller, A. El hombre del Renacimiento. Barcelona, Península, 1980.

Horkheimer, M. /Adorno, Th. W. Dialéctica de la Ilustración. Madrid, Trotta, 2001.

Jarauta, F., Buci-Glucksmann, Chr. Barroco y Neobarroco. Madrid, Círculo de Bellas Artes, 1992. 
Jaspers, K. «Lo trágico», en Lo trágico. El lenguaje. Granada, Ágora, 1995.

Lyotard, J.-F. La condición posmoderna. Madrid, Cátedra, 1989.

Maravall, J.A. La cultura del barroco. Barcelona, Ariel, 1990.

Marcuse, H. El hombre unidimensional. Barcelona, Ariel, 1981.

Marx, K. y Engels, F. Manifiesto comunista. Madrid, Akal, 1997.

Nietzsche, F. Fragmentos póstumos. Madrid, Tecnos, 2006.

Nietzsche, F. Más allá del bien y del mal. Madrid, Alianza, 1997.

Pelegrín, B. Figurations de l'infini. L'âge baroque européen. París, Seuil, 2000.

Rorty, R. Contingencia, Ironía y Solidaridad. Barcelona, Paidós, 1991.

Rorty, R. «Wittgenstein, Heidegger und die Hypostasierung der Sprache», en McGuiness (ed.). Der Löwe spricht... und wir können ihn nicht verstehen. Frankfurt a. M., Suhrkamp, 1991, pp. 69-93.

Rossi, M. J. «Cartografías del barroco en América Latina». Ekstasis. Revista de hermenêutica e fenomenologia. V. 5, $\mathrm{n}^{\mathrm{o}} 1$ (2016), pp. 91-121.

Sáez Rueda, L. El ocaso de Occidente. Barcelona, Herder, 2015.

Sáez Rueda, L. Ser errático. Una ontología crítica de la sociedad. Madrid, Trotta, 2009.

Sarduy, S. «Nueva inestabilidad», en Ensayos generales sobre el barroco. México-Buenos Aires, F.C.E., 1987, pp. 9-52.

Sarduy, S. «El Barroco y el Neobarroco», en Fernández Moreno, C. (coord.). América Latina en su literatura. México-París, Siglo XXI/Unesco, 1972.

Schmitt, C. Teología política. Madrid, Trotta, 2009.

Taylor, Ch. Fuentes del yo. Barcelona, Paidós, 1996.

Trías, E. «Escenificación del infinito (interpretación del Barroco)», en Lo bello y lo siniestro. Barcelona, Ariel, 1996.

Vattimo/otros. El pensamiento débil. Madrid, Cátedra, 1990.

Villacañas, J.L. «Gracián en el paisaje filosófico alemán. Una lectura desde Walter Benjamin, Arthur Schopenhauer y Hans Blumenberg», en Grande, M./Pinilla J. (eds.). Gracián: Barroco y modernidad. Universidad Pontificia de Comillas de Madrid, 2004, pp. 283-306.

Wellmer, A. Finales de partida: la modernidad irreconciliable. Madrid, Cátedra, 1996. 